\title{
PERAN USAHA MIKRO KECIL MENENGAH (UMKM) DALAM PEREKONOMIAN NASIONAL
}

\author{
Irma Setyawati \\ STIMA KOSGORO
}

\begin{abstract}
It is believed that the development UMKM will strengthen the national economics, with a consideration that generally UMKM is based on the local economic human resources and do not based on import. It is expected that the uniqueness products can be exported. The objective of the article is to describe the role UMKM related to the national economy, especially the investment support for UMKM to improve the economic growth, the labour absorbing. The method used data collecting from ibrary research and other related sources. The resuit shows that UMKM plays an important part in growing the new entrepreneurs based an the science and technology.
\end{abstract}

\section{PENDAHULUAN}

Struktur perekonomian nasional masih mengandung berbagai ketimpangan dengan pertumbuhan yang masih berpusat di Jawa. Hal ini dindikasikan oleh jumlah uang beredar, alokasi kredit, pajak, dan alokasi sumberdaya produktif lainnya terfokus di daerah tersebut. Untuk itu, perlu ada komitmen bersama untuk menumbuhkan pusat-pusat aktivitas ekonomi di daerah melalui reformasi pembangunan ekonomi yang mampu mengembangkan sumberdaya lokal dan menggerakkan ekonomi rakyat yang lebih produktif dan berdaya saing.

Dalam masa pemulihan, perkonomian nasional terus tumbuh, namun pertumbuhannya lebih dominan pada sektor konsumsi dan bukan sektor produksi. Rendahnya tingkat investasi dan produktivitas, serta rendahnya pertumbuhan usaha baru di Indonesia perlu memperoleh perhatian yang serius pada masa mendatang, dalam rangka mengembangkan Usaha Mikro, Kecil, dan Menengah (UMKM) menuju usaha yang berdaya saing tinggi. Pengembangan UMKM diyakini akan memperkuat ekonomi nasional, dengan beberapa pertimbangan bahwa UMKM pada umumnya berbasis pada sumber sumberdaya ekonomi lokal dan tidak bergantung pada impor, serta hasilnya mampu diekspor karena keunikannya. Perekonomian Indonesia akan memiliki fondasi yang kuat, jika UMKM menjadi pelaku utama yang produktif dan berdaya saing dalam perekonomian nasional. Untuk itu, pembangunan usaha mikro, kecil, dan menengah perlu menjadi prioritas utama pembangunan ekonomi nasional dalam jangka panjang.

Permasalahan UKMM antara lain keterbatasan fasilitas kredit mikro, prosedur dan persyaratan kredit perbankan yang rumit dan birokratis dan tingginya bunga kredit serta kurang sosialisasi produk pinjaman dan keterbatasan pelayanan kredit. Padahal kalau pemberdayaan UMKM dilakukan, maka peranan UMKM sangat strategis, karena potensinya yang besar dalam menggerakkan kegiatan ekonomi masyarakat dan sekaligus menjadi tumpuan sumber pendapatan sebagian besar masyarakat dalam meningkatkan kesejahteraannya. Di samping itu, UMKM sebagai salah satu sumber penting bagi pertumbuhan Produk Domestik Bruto (PDB) dan ekspor non migas. Tujuan dari penulisan makalah ini adalah membahas tentang peranan UMKM dalam perekonomian nasional, terutama dukungan investasi bagi UMKM dalam 
meningkatkan pertumbuhan ekonomi, penyerapan tenaga kerja. Metode penulisan bersumber pada pengumpulan data dan studi kepustakaan (library Research)

\section{PEMBAHASAN}

Menegkop dan UKM mendefinisikan usaha kecil (UK). termasuk usaha mikro (UMI), sebagai suatu badan usaha milik warga negara Indonesia, baik perorangan maupun berbadan hukum yang memiliki kekayaan bersih, tidak termasuk tanah dan bangunan sebanyakbanyaknya Rp 200 juta dan atau mempunyai hasil penjualan rata-rata per tahun sebanyak Rp 1 milyar dan usaha tersebut berdiri sendiri. Badan usaha milik warga negara Indonesia yang memiliki kekayaan bersih lebih besar dari $R p 200$ juta sampai dengan $R p 10$ milyar tidak termasuk tanah dan bengunan tempat usaha didefinisikan sebagai usaha menengah (UM). Badan usaha dengan nilai aset dan omzet di atas itu adalah usaha besar (UB). Sedangkan Badan Pusat Statistik (BPS) mendefinisikan skala usaha berdasarkan jumlah tenaga kerja. UK adalah perusahaan (baik berbadan hukum atau tidak) yang mempunyai tenaga kerja berjumlah $5-19$ orang termasuk pemilik usaha atau pengusaha dan UMI adalah usaha dengan tenaga kerja $1-4$ orang. Sedangkan UM adalah perusahaan yang mempekerjakan $20-29$ orang. Perusahaan dengan jumlah tenaga kerja lebih dari 99 orang dikategorikan sebagai UB.

UKM terdapat di semua sektor ekonomi, termasuk industri manufakturing dan perdagangan. Oleh karena industri dan dagang kecil (IDK) tergolong dalam batasan UK menurut Undang-undang No. 9 tahun 1995 tentang UK, maka batasan IDK didefinisikan oleh Departemen Perindustrian dan Perdagangan (Deperindag) sebagai kegiatan ekonomi yang dilakukan secara persecrangan atau rumah tangga maupun suatu badan, bertujuan untuk memproduksi barang maupun jasa untuk diperniagakan secara komersial.

Secara umum peran usaha mikro dan kecil dalam pembentukan Produk Domestik Bruto (PDB) mengalami kenaikan dibanding sebelum krisis, bersamaan dengan merosotnya usaha menengah dan besar, terutama pada puncak krisis ekonomi tahun 1998 dan 1999, namun kemudian tergeser kembali oleh usaha besar. Usaha kecil telah pulih dari krisis pada tahun 2001, dan usaha besar baru pulih dari krisis pada tahun 2003, sedang untuk usaha menengah diperkirakan pulih pada tahun 2004 Krisis ekonomi mengakibatkan Indonesia tertinggal tujuh tahun dibandingkan negara lain dalam membangun daya saing perekonomian nasionalnya. Usaha mikro dan kecil umumnya memiliki keunggulan dalam bidang yang memanfaatkan sumberdaya alam dan padat karya, sepert pertanian tanaman pangan, perkebunan, peternakan. perikanan, perdagangan, dan restoran. Usaha menengah memiliki keunggulan datam penciptaan nilai tambah di sektor hotel, keuangan, persewaan, jasa perusahaan. dan kehutanan. Usaha besar memiliki keunggulan dalam industri pengolahan, listrik dan gas, komunikasi, dan pertambangan. Hal ini membuktikan usaha mikro, kecil, menengah, dan usaha besar di dalam praktek bisnisnya saling melengkapi.

Membaiknya kinerja sektor riil tercermin melalui unit usaha yang meningkat hampir di semua lapangan usaha. Secara global populasi UK pada seluruh sektor ekonomi jumlahnya meningkat dari tahun 2003 ke tahun 2005 Jumlah unit usaha UKM meningkat dari 42.395 .020 unit di tahun 2003 menjadi 44.689 .588 unit di tahun 2005 . Sementara jumlah unit UB naik dari 3.894 unit menjadi 4.171 unit dan jumlah UK meningkat dari 42.331.474 menjadi 44.621 .823 pada tahun 2005. Perkembangan jumlah UKM periode 2006-2007 mengalami peningkatan sebesar 2,18 persen yaitu dari 48.779 .151 unit pada tahun 2006 menjadi 49.840 .489 unit pada tahun 2007. seperti terlihat pada tabel 1 di bawah ini:

Tabel 1: Perkerrbangan Jumlah Pelaku Usaha Menurut Skala Usaha Tahun 2006-2007,

\begin{tabular}{|c|c|c|c|c|c|}
\hline \multirow{2}{*}{ No. } & \multirow{2}{*}{ SKALA USAHA } & \multicolumn{2}{|c|}{ SUMLAH (Unit) } & \multicolumn{2}{|c|}{ PERKEMBANGAN } \\
\hline & & TAHUN 2006 & TAHLN 2097 & JUMLAH & $(\%)$ \\
\hline 1. & Uahien Mbro & 40.785 .657 & 47302310 & 955.743 & 204 \\
\hline 2 & Usha Keei (ItK) & $1.5 \mathrm{t}$. & 2017.906 & 100.029 & $\$ 22$ \\
\hline \multirow[t]{3}{*}{3.} & Ussha Merergah (UN) & 114697 & $12 \ln 250$ & 5504 & 4.85 \\
\hline & Waiha Ked ctm & & & & \\
\hline & Menengin (LiROU)! & $\operatorname{sen} 7.151$ & 48.640 .489 & 1.0n1:20n & $2+8$ \\
\hline 4 & Ustha Bosar (UD) & 4.398 & 4587 & 120 & 293 \\
\hline 8 & JUVLA & c).7nx.549 & 49z4sans & 1.081 .467 & 2,18 \\
\hline
\end{tabular}




\section{EKONOMI}

Peran UMKM dalam perekonomian Indonesia paling tidak dapat dilihat dan: (1) kedudukanmya sebagai pemain utama dalam kegiatan ekonomi di berbagai sektor, (2) penyedia lapangan kerja yang terbesar, (3) pemain penting dalam pengembangan kegiatan ekonomi lokal dan pemberdayaan masyarakat, (4) pencipta pasar baru dan sumber inovasi, serta (5) sumbangannya dalam menjaga neraca pernbayaran melalui kegiatan ekspor. Posisi penting ini sejak dilanda krisis belum semuanya berhasil dipertahankan, sehingga pemulihan ekonomi belum optimal. Untuk mencapai sasaran pembangunan ekonomi, UMKM perlu memperoleh perhatian, karena, Pada kondisi ekonomi Indonesia saat ini relatif akan sulit menarik investasi. Untuk itu, keterbatasan investasi pertu diarahkan pada upaya mengembangkan wirausaha baru. Seperti terlihat pada tabel 2, pada tahun 2006 , nilai investasi UKM tercatat sebesar Rp. 307.626.544. Pada tahun 2007, nilai investasi UKM meningkat $24,66 \%$ atau menjadi Rp 462.011.653.

Dalam situs Antara News (www.antara,co.id), nilai investasi yang berasal dari Penanam Modal Dalam Negeri (PMDN) tercatat Rp20,78 triliun pada tahun 2006. Hal ini berarti peran UKM dalam pembentukan investasi nasional sebesar $1,5 \%$. Pada tahun 2007, nilai investasi yang berasal dari Penanam Modal Dalam Negeri (PMDN) tercatat Rp31,14. Pada tahun tersebut peran UKM dalam pembentukan investasi nasional tetap sebesar $1,5 \%$.

Tabel 2: Perkembangan Nilai Investasi Menurut Skala Usaha Tahun 2006-2007, Atas Dasar Harga Berlaku.

\begin{tabular}{|c|c|c|c|c|c|}
\hline \multirow{2}{*}{ No. } & \multirow{2}{*}{ SKALA LSAHA } & \multicolumn{2}{|c|}{ JUMLAH (Unit) } & \multicolumn{2}{|c|}{ PERKE ESBANGGAN } \\
\hline & & TAHUN 2006 & TAHDN 2007 & JUALAH & $(*)$ \\
\hline i. & Usxan Ked (UK) & 184.75006 & 204.008 .061 & 40003025 & 24.29 \\
\hline \multirow[t]{3}{*}{2.} & Utara Mernengat fUM) & $205848.50 \%$ & 207.202 .692 & 51.354 .185 & 2435 \\
\hline & Usana Kotie der & & & & \\
\hline & Monengah fUKA) & 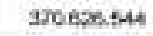 & Q:2011.653. & 91385.109 & 2465 \\
\hline \multirow[t]{2}{*}{3} & Usuta Busar (NA) & 434843.766 & 521.821 .100 & 86.967 .343 & 20.00 \\
\hline & JUMLAH & 300.470 .310 & $36382276 s$ & 170.352 .243 & 22,14 \\
\hline
\end{tabular}

Dengan kestabilan nilai investasi UKM, maka usaha pemerintah untuk meningkatkan mustiplier effect dengan akan menambah jumlah bank pelaksana penyaluran kredit usaha rakyat (KUR) dengan menggandeng sepuluh Bank Pemerintah Daerah (BPD) agar realisasi pinjaman program tersebut bisa lebih besar dan mengakses ke kantong-kantong usaha mikro kecil dan menengah sampai ke pelosok: Sejumlah BPD yang digandeng itu adalah PT Bank DKI, PT Bank Jabar-Banten, PT Bank Jateng، PT Bank Yogyakarta, PT Bank Jatim, PT Bank Suiset, PT Bank Sumut, PT Bank Riau, PT Bank Bali dan PT Bank Sumsel.

Usaha mikro, kecil, dan menengah memberikan lapangan kerja bagi 99,45\% tenaga kerja di Indonesia, dan masih akan menjadi tumpuan utama penyerapan tenaga kerja pada masa mendatang. Hal ini merupakan bukti bahwa UMKM merupakan katup pengaman, dinamisator, dan stabilisator perekonomian Indonesia. Berdasarkan data, UKM mampu menyerap $97,34 \%$ atau 89.547.762 tenaga kerja dari total penyerapan tenaga kerja yang ada di Indonesia pada tahun 2006. Kontribusi UK dalam penyerapan tenaga kerja tercatat sebesar 85.053.069 orang atau $92,46 \%$ dan UM sebanyak 4.494 .693 orang atau $4,89 \%$. Pada tahun 2007 , UKM mampu menyerap $97,33 \%$ atau $91,752,318$ tenaga kerja dari total penyerapan tenaga kerja yang ada. Kontribusi UK dalam penyerapan tenaga kerja tercatat sebesar 87.032 .313 orang atau $92,32 \%$ dan UM sebanyak 4.720 .005 orang atau $5,01 \%$. Perkembangan jumlah penyerapan tenaga kerja menurut sektor skala usaha ditihat pada tabel 3.

Tabel 3: Perkembangan Jumlah Penyerapan Tenaga Kerja menurut Skala Usaha Tahun 2006-2007

\begin{tabular}{|c|c|c|c|c|c|}
\hline \multirow{2}{*}{ No. } & \multirow{2}{*}{ SKALA USAHA } & \multicolumn{2}{|c|}{ JUML AH (Unig) } & \multicolumn{2}{|c|}{ PERKKEMRANGAN } \\
\hline & & TAHUN 2606 & TAHUN 2007 & JUMLAH & $(\%)$ \\
\hline 1. & Loutan Wivo & 75.450 .589 & 77.001680 & 1 exp.c00 & 2,19 \\
\hline 2 & Whata Kace (1) & 6099400 & $99 \mathrm{~s} 0 \mathrm{~s} 4 \mathrm{H}$ & 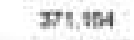 & 3.87 \\
\hline \multirow[t]{3}{*}{3.} & Laka Marnerghth (GM? & 4.404690 & 4720005 & 225312 & 5,01 \\
\hline & Lewea Kaed on & & & - & \\
\hline & Menengah (LxOM) & $\operatorname{BDSCTQ}$ & 91752318 & 2204.581 & 2,46 \\
\hline \multirow[t]{2}{*}{4.} & Lhare Besar (UA) & 2445.50 & 2520.707 & 75.112 & 300 \\
\hline & JUMLAK & $91.923 .25 t$ & 34273.025 & 221965 & 2,48 \\
\hline
\end{tabular}

Berkembangnya wirausaha sebanyak 7,67 juta selama tahun 2002 - 2007, dengan asumsi kemampuan penyerapan tenaga kerja oleh usaha kecil sebesar 1,6 orang tenaga kerja per unit usaha, maka usaha kecil diharapkan mampu memberikan lapangan kerja baru bagi 10,67 juta orang Jika pertumbuhan penyerapan tenaga kerja oleh sektor usaha besar dan menengah konsisten, 
maka sasaran pengangguran sebesar $5,1 \%$ atau hanya 5,94 juta orang menganggur. Berarti sebanyak 110,6 juta orang bekerja dari perkiraan 116.516 juta angkatan kerja pada tahun 2009 akan dapat dicapai. Bahkan, jika pengembangan kewirausahaan dan penumbuhan unit usaha baru dilaksanakan secara optimal, pengangguran terbuka akan dapat ditekan pada angka $3,28 \%$ pada tahun 2009 . Perhitungannya tahun 2007 , jumlah angkatan kerja di indonesia 103,416 juta orang. yang bekerja 92,057 juta orang dan yang menganggur 11,359 juta orang. Dengan asumsi kemampuan penyerapan tenaga kerja yang ada hanya 2 juta per tahun yang berarti 10 juta dalam lima tahun ditambah 10,67 juta dari wirausaha baru, maka perkiraan jumlah penduduk yang bekerja pada tahun 2009 sekitar 112,7 juta orang, yang berarti tingkat pengangguran dalam kisaran $3,28 \%$.

\section{Produktivitas Pembentukan PBD Usaha Mikro dan Kecil}

Produktivitas pembentukan PDB usaha mikro atas dasar harga konstan tahun 2000 sebesar Rp 1,847,29 triliun, peran UKM tercatat sebesar Rp 1.035,61 triliun atau $56,06 \%$ dari total PDB nasional, kontribusi UK tercatat sebesar Rp 726,01 triliun atau 39,30\% dan UM sebesar Rp 309,61 triliun atau $16,76 \%$. Sedangkan produktivitas pembentukan PDB usaha mikro atas dasar harga konstan tahun 2000 sebesar Rp 1.963,97 triliun, peran UKM tercatat sebesar Rp 1.101,64 triliun atau $56,09 \%$ dari total PDB nasional, kontribusi UK tercatat sebesar Rp 770,85 triliun atau $39,25 \%$ dan UM sebesar Rp 330,79 triliun atau $16,84 \%$. Hal tersebut djelaskan dalam tabel 4.

Tabel 4: Perkembangan Nilai Produk Domestik Bruto (PDB) Menurut Skala Usaha Tahun 2006-2007 atas Dasar Harga Konstan 2000

\begin{tabular}{|c|c|c|c|c|c|}
\hline \multirow{2}{*}{ NO. } & \multirow{2}{*}{ SKALA USAMA } & \multicolumn{2}{|c|}{ JUMLAH (Uhit) } & \multicolumn{2}{|c|}{ PERKKEMEANGAN } \\
\hline & & TAHUN $2006 \mathrm{~T}$ & TAHUN 2007 & JUREAM & $\left\{x_{6}\right\}$ \\
\hline 2. & Uiaran Kedi (UK) & 725.0069 & $770,852,4$ & 44,6454 & 8.98 \\
\hline \multirow[t]{3}{*}{2.} & Usara Menengah fUM] & 309.6063 & $330,7 \mathrm{es}, \mathrm{B}$ & $21,18 a 5$ & 6,84 \\
\hline & Uera kect din & & & & \\
\hline & Monange (UKU) & 1.0356123 & t. 101005.2 & $66,025.9$ & 6,38 \\
\hline \multirow[t]{2}{*}{3} & Ueata Besax \{Le\} & 811.6000 & $1862,335,1$ & $50,655.5$ & 6,24 \\
\hline & JUMLAN & 1.847 .250 .2 & t.901974,3 & $16.681,4$ & 6,37 \\
\hline
\end{tabular}

Peningkatan ini diharapkan akan meningkatkan pendapatan per kapita dari kelompok mayoritas penduduk terbawah dari US\$ 431,6 menjadi US\$ 875,9 per kapita (Rasio tenaga kerja : penduduk $=1: 2,69$ pada tahun 2003 menjadi 1: 2,04 pada tahun 2009). Pemberdayaan UKM akan membantu upaya meningkatkan pendapatan per kapita, dan sekaligus meningkatkan pemerataan pendapatan masyarakat, sehingga upaya menurunkan tingkat kemiskinan di bawah $8,2 \%$ pada tahun 2009 dapat dicapai.

\section{Stabilitas Ekonomi Makro}

Pengembangan UMKM diharapkan akan meningkatkan stabilitas ekonomi makro karena menggunakan bahan baku lokal dan memiliki potensi ekspor, sehingga akan membantu menstabilkan kurs rupiah dan tingkat inflasi. Pembangunan UMKM akan menggerakkan sektor riil karena UMKM umumnya memiliki keterkaitan industri yang cukup tinggi Sektor UMKM diharapkan akan menjadi tumpuan pengembangan sistem perbankan yang kuat dan sehat pada masa mendatang, mengingat nonperforming loan-nya yang relatif sangat rendah. Pengembangan UMKM juga akan meningkatkan pencapaian sasaran di bidang pendidikan, kesehatan, dan indikator kesejahteraan masyarakat indonesia lainnya:

\section{Kehidupan Yang Aman, Damai, Adil, Demokratis dan Sejahtera}

Adanya lapangan kerja dan meningkatnya pendapatan diharapkan akan membantu mewujudkan masyarakat Indonesia yang aman dan damai, adil dan demokratis. serta sejahtera. Untuk mewujudkan keamanan yang nyata, masyarakat tidak dapat hidup dalam kemiskinan dan tingkat pengangguran yang tinggi. Untuk mewujudkan demokrasi, tidak terjadi ketimpangan ekonomi di masyarakat, serta sulit mewujudkan keadilan hukum, jika ketimpangan penguasaan sumberdaya produktif masih sangat nyata. Pembangunan UMKM merupakan salah satu jawaban untuk mewujudkan visi Indonesia yang aman, damai, adil, demokratis, dan sejahtera.

\section{PENUTUP}

\section{Kesimpulan}

1. UMKM menempati posisi strategis untuk mempercepat 


\section{EKONOMI}

perubahan struktural dalam rangka meningkatkan taraf hidup rakyat banyak dan merupakan wadah kegiatan usaha bersama bagi produsen maupun konsumen. 2. UMKM berperan dalam memperluas penyediaan lapangan kerja, memberikan kontribusi yang signifikan terhadap pertumbuhan ekonomi, dan memeratakan peningkatan pendapatan serta meningkatnya daya saing dan daya tahan ekonomi nasional.

3. UMKM berperan dalam menumbuhkan wirausaha baru berbasis ilmu pengetahuan dan teknologi.

\section{Saran-saran}

1. Perlu dikembangkan usaha kecil dan menengah (UKM) untuk memberikan kontribusi yang signifikan terhadap pertumbuhan ekonomi, penciptaan lapangan kerja, dan peningkatan daya saing.

2. Perlu memperkuat kelembagaan dengan menerapkan prinsip-prinsip tata kepemerintahan yang baik (good govemance) dan berwawasan gender, terutama untuk memperluas akses kepada sumber permodalan, khususnya perbankan.

3. Memperbaiki lingkungan usaha dan menyederhanakan prosedur perijinan dan memperluas dan meningkatkan kualitas institusi pendukung yang menjalankan fungsi intermediasi sebagai menyedia jasa pengembangan usaha, teknologi, manajemen, pemasaran dan informasi 4. Meningkatan kualitas SDM dan mengintegrasikan pengembangan usaha dalam konteks pengembangan regional.

\section{DAFTAR PUSTAKA}

Republik indonesia, Undang-Undang Nomor 25 Tahum 1992, fentang Purhaperasian

- Undang-Undang Namar 9 Tahun 1995, fentang Usaha Kocil

Peraturan Presiden Nomor 7 Tahum 2005, tentang Rencana Pembanguras Jangka Mtenengah Tahur $2004-2009$

Harinowo, Cyrillus, Musim Semi Perekonomian Indonesia, PT Gramedia Pustaka Utama, Jakarta, 2005.

Kementerian Koperasi dan UKM, Rencana Stralegis Pembangunan Koperasi dan UMKM Periode Tahun 2004 - 2009, Jakarta, 2004.

Pramono, Penny R, Seri Usaha Kecl Menengah: Mvestasi Saya Berakhit di Karung Emas afau Keranjang Sampah?. Elex Media Komputindo, Jakarta, 2007

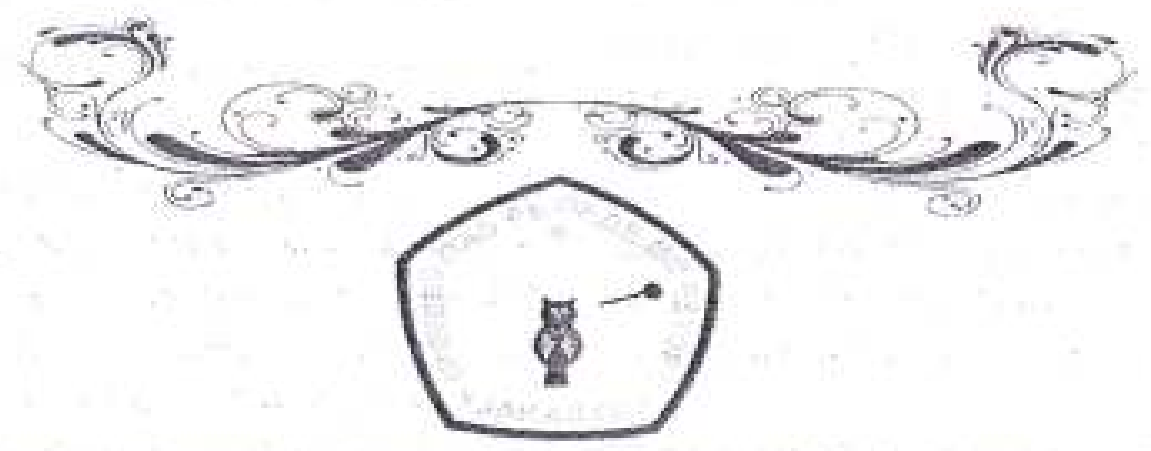

Segenap Keluarga Besar Universitas Prof. DR. Moestopo (Beragama)

\section{Mengucapkan}

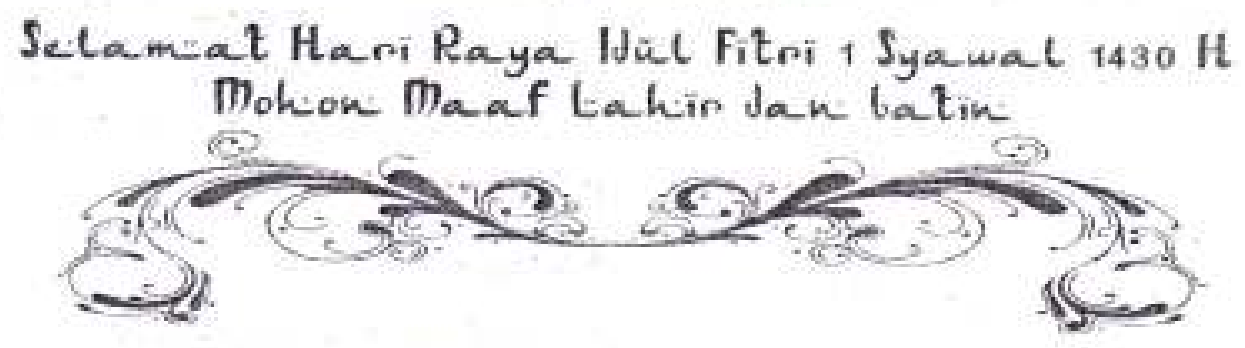

